\title{
Examining the current law relating to limitation and causes of action (tortious and contractual) within a construction context
}

Received (in revised form): 11th September, 2005

\section{Sarah Wilson}

is an associate solicitor within Watson Burton LLP's Construction Law Unit, one of the largest specialist construction legal departments outside of London. Sarah's clients vary from developers and main contractors through to design professionals and subcontractors. She specialises in large-scale, high-value engineering and construction disputes and has widereaching experience of various dispute resolution forums such as the Technology and Construction Court, arbitration, adjudication and mediation. She is an associate of the Chartered Institute of Arbitrators and is a committee member of the Northumbria branch.

\begin{abstract}
This paper carries out an examination of the current law relating to limitation and causes of action (tortious and contractual) within a construction context and explains the main provisions from the Limitation Act 1980. It further analyses application of the 1980 Act in light of the recent decision, Abbott $v$ Will Gannon \& Smith Ltd. This new judgment involved analysis and reconciliation of the decisions in the key cases: Murphy $v$ Brentwood DC and Pirelli General Cable Works Limited v Oscar Faber \& Partners. Although the case law in this area sets out the principles for limitation and causes of action in general law the decisions come from construction-based disputes and are relevant to the author's legal specialism.
\end{abstract}

\section{Keywords:}

limitation, cause of action, tortious/contractual, Limitation Act 1980

Watson Burton LLP 1 St James' Gate

Newcastle upon Tyne NE99 1YQ, UK Tel: + 44 (o) 1912444444

E-mail: sarah.wilson@watsonburton. com

\section{INTRODUCTION}

A builder who causes damage in the course of construction is liable for losses that result. Construction consultants, on the other hand, provide advice (sometimes in the form of design) which raises problems when it turns out to be negligent. In particular, with regard to the time limits to bring proceedings, does time start to run when the advice is given, when the building is complete or when the damage occurs? These are the issues considered in the cases reviewed in this paper.

The issue to be considered by the Court of Appeal judges in the case of Abbott $v$ Will Gannon \& Smith Ltd [2005] EWCA CIV 198 (hereinafter referred to as 'Will Gannon') was whether Murphy v Brentwood DC [1991] AC398 ('Murphy') was inconsistent with Pirelli General Cable 
Works Limited v Oscar Faber \& Partners [1983] 2 AC1 ('Pirelli') and, if so, whether Pirelli was still good law.

In Pirelli, the House of Lords found that, for limitation purposes, the cause of action against the consulting engineer for negligent design accrued when physical damage to the building first occurred. This decision had been followed by the Deputy District Judge who gave the first instance decision on Will Gannon.

The argument put forward on behalf of the engineers was that in Murphy the Court of Appeal had found that a cause of action accrues when the building owner suffers economic loss and that this was when the negligently designed work had been completed because it was at this stage that the building required remedial work.

\section{ABBOTT v WILL GANNON}

\section{The facts of the case}

Abbott v Will Gannon

The facts of Will Gannon are indistinguishable from those in Pirelli. A summary of Pirelli is detailed further on in this paper but, in the meantime, the facts of Will Gannon are summarised below.

\section{May 1995}

The defendant consulting structural and civil engineers were engaged by the claimant, who owned a hotel in Torquay, to design the work to remedy structural defects to a bay window in the hotel.

\section{March 1997}

The work, in accordance with the engineer's design, was completed by a third party.

\section{Late 1999}

The claimant hotel owner first noticed that the lintel over the bay window had moved and caused cracking. The claimant had to spend circa $£ 20,000$ to remedy this problem.

\section{5th September, 2003}

Proceedings in contract and tort were issued against the engineer upon the following basis:

- there was a breach of contract/duty of care;

- such breaches had caused the defects which appeared in 1999; and

- claiming the cost of repair and consequential losses.

\section{Procedural points}

Before reviewing the arguments put forward by the parties it would be helpful to note these procedural points to get a fuller view of the extent of this case. The contract was not in writing but it was agreed that it 
contained the usual implied term that the engineers would carry out the work with reasonable care and skill. The parties had reached agreement that the contract claim was out of time and that this left only the tortious claim. The limitation point was tried as a preliminary issue on facts agreed between the parties.

\section{Legal issue}

For the tortious claim to proceed the proceedings must be commenced within six years (under Section 2 of the Limitation Act 1980) of the accrual of the claim. The claim accrues when the damage occurs. Therefore, under Section 2, the question was when the cause of action accrued: was it when the work was completed (March 1997) as contended by the engineers - in which case the claim was time barred — or was it when the damage occurred to the building (and the claimant contended that this was shortly before he first noticed the cracking in late 1999) — in which case it was not time barred.

The judge at first instance had not made a specific finding on these points but found in favour of the claimant, stating: 'if cracks first appeared within six years of the issue of proceedings [the claim] is not statute barred'. As the cracks appeared in 1999 and proceedings were commenced in 2003 they were not statute barred.

\section{Limitation Act 1980}

\section{BACK TO BASICS - THE LIMITATION ACT 1980}

It may be helpful to review the relevant statute in relation to time limits for commencing proceedings prior to a review of the cases referred to by the Court of Appeal in Will Gannon. The Limitation Act 1980 has been referred to previously and the relevant extracts are quoted in the Appendix to this paper.

The Limitation Act 1980 is the statutory instrument which defines the time limits within which court proceedings must be commenced. Failure to comply with those time limits means proceedings cannot be commenced/proceed and it is up to the claimant to show that the proceedings have been brought within the relevant time limits. It is therefore crucial that the time limits are observed. There are important differences between claims in contract and claims in tort.

\section{Contract}

While this paper deals with tortious claims rather than contractual claims, it may be helpful to note the contrast made. The ordinary time limit for a claim in a simple contract is six years from the date on which the cause of action accrues (Section 5), whereas for a contract by deed the time limit is 12 years (Section 8). In both cases, time starts to run from the date of breach of contract and not from the date of its discovery.

Having said that, where a contractor is responsible under an entire contract to complete works, the limitation period for defects generally runs from the date of completion rather than from any earlier date when that part of the works, relevant to the subject matter of the defects, was carried out. 


\section{Tort}

The time limit for a claim in tort (for example, negligence) is generally six years from the date on which the cause of action accrues (Section 2). For negligence claims, where damage is an essential ingredient, the cause of action accrues when the damage occurs. It is therefore quite common for the limitation period on a simple contract claim to expire prior to the tortious claim.

It should be noted that Section 14A, an amendment to the Limitation Act by way of the Latent Damage Act 1986, provides a special time limit for negligence claims where facts relevant to the cause of action are not known at the date of accrual. Essentially, it extends the primary limitation period (six years) by three years from the claimant's date of knowledge in respect of the damage. This was of no assistance in Will Gannon, however, as the date of knowledge was late 1999 and the three-year period expired in late 2002.

\section{PIRELLI}

\section{The facts of the case}

In this case the engineer negligently designed a chimney for a factory belonging to the plaintiff. The chronology was as follows.

\section{July 1969}

Construction of the chimney was completed.

\section{By April 1970}

Cracks had developed in the chimney which remained undiscovered (ie more than eight years before the proceedings were issued).

\section{November 1977}

The cracks were discovered and required remedial works.

\section{October 1978}

Proceedings were issued by the claimant following the remedial works.

\section{Legal arguments}

The defendant suggested three possible dates for the start of the Limitation Period:

- the date when the plaintiff relied upon the negligent advice (ie prior to July 1969);

- the date when the construction was completed (July 1969);

- the date when the cracks first occurred (prior to April 1970).

The plaintiff argued that the start of the Limitation Period was the date when the damage was discovered or, with reasonable diligence, ought to 
have been discovered (and presumably it was argued that this date was November 1977).

\section{The decision in Pirelli}

The decision was that the cause of action accrued when the physical damage first occurred to the building. In this case, it was spring 1970, being the date when the cracks to the chimney must have come into existence. This meant that the claimant had failed to commence proceedings within six years of the accrual of the cause of action and the claim therefore failed.

It should be noted that this case pre-dates the amendment of the Limitation Act 1980 by the Latent Damage Act 1986 and therefore Section 14A (as referred to above) whereby the Limitation Period can be extended for a further three years from the claimant's 'date of knowledge' (in this case November 1977) was of no assistance to the claimant. Indeed, it was as a result of the perceived injustice in Pirelli that Section 14A was introduced into the 1980 Act.

\section{'Doomed from the start' argument}

The judgment in Pirelli suggested that, while generally speaking a cause of action accrues only when physical damage has occurred to a building, there could be an exception to this where the advice of an architect or consulting engineer leads to the erection of a building which 'is so defective as to be doomed from the start'. This point was considered in the further House of Lords case, Ketteman v Hansel Properties [1987] AC189 ('Ketteman'), which in turn was considered in Will Gannon.

\section{KETTEMAN v HANSEL}

\section{The facts}

Very briefly, the facts of this case were that houses had been built on defective foundations and the architects, defending allegations of defective design, argued that the cause of action accrued when the

\section{Ketteman v Hansel} foundations for the houses were laid by the builders. This argument was based on the idea that the houses were doomed from the start and so this was the point at which the plaintiff suffered economic loss, ie when the houses became less valuable than they would have been had the foundations been adequate.

Counsel for the defendant put forward an argument that the buyer suffered two kinds of damage as follows.

- The first was physical damage, in which case the cause of action for negligence accrued when the physical damage occurred.

- The second was economic loss, ie diminution in value, which occurred at the time of construction.

\section{Decision}

This argument was rejected. The court found that the defects in the houses were latent, no one knew of their existence until the damage occurred and 
it was only when the damage had occurred that a cause of action arose. The judgment cited and approved Pirelli in respect of the proposition that a latent defect in a building does not give rise to a cause of action until damage occurs.

The court referred to the 'doomed from the start' point made in Pirelli. Lord Keith was of the view that the judges in Pirelli had not intended this argument to apply to latent defects which would eventually result in damage because Pirelli concerned such a defect and the court had found that the cause of action accrued when damage occurred. Lord Brandon, in Ketteman, suggested that it was an attempt to leave an opening for special cases. But his opinion was that there had been no attempt in Pirelli to differentiate between causes of action where the claimant was seeking to:

- make good defects, ie physical damage; and

- recover the diminution in market value, ie economic loss.

\section{MURPHY V BRENTWOOD DC}

\section{The facts}

This is another case regarding a house built on defective foundations, although there were no limitation issues. In this case, the claimant brought proceedings against Brentwood District Council to recover the diminution in the market value of the house. Essentially, this case deals with tortious liability with regard to latent defects and distinguishes between:

- defects which cause injury to an individual or damage to property; and - those that do not.

Murphy $\boldsymbol{v}$ Brentwood DC In the latter case, the loss sustained by the building owner was economic - either the defective property could be repaired and the cost of repair was the loss sustained or, if the defect could not be repaired, the loss was the reduced value of the property. As economic losses they are only recoverable if they flow from breach of a relevant contractual duty but are not recoverable in tort unless there is some 'special relationship of proximity'.

In his judgment on Murphy, Lord Keith commented upon Pirelli stating:

\footnotetext{
'If the plaintiffs had happened to discover the defect before any damage had occurred there would seem to be no good reason for holding that they would not have had a cause of action at that stage, without having to wait until some damage had occurred. They would have suffered economic loss through having a defective chimney upon which they required to expend money for the purpose of removing the defect ... where the tortious liability arose out of a contractual relationship with professional people, the duty extended to take reasonable care not to cause economic loss to the client by the advice given.'
}

This was all examined in Will Gannon, however, and the view was that it does not obviously overrule Pirelli but merely deals with the situation 
Invercargill City Council v Hamlin where the claimant discovers the defect before the damage occurs and concludes that the claimant has a claim for economic loss if there is a special relationship.

\section{INVERCARGILL CITY COUNCIL v HAMLIN}

Invercargill City Council v Hamlin [1996] AC624 ('Invercargill') was a New Zealand Privy Counsel case which examined both Pirelli and Murphy and was itself examined in Will Gannon. The New Zealand courts took a completely different approach to Pirelli which is illustrated by this case.

It was stated in Invercargill that: "the cause of action accrues when the cracks become so bad and all the defects so obvious, that any reasonable home-owner would call in an expert'. The New Zealand courts therefore look for the date when the physical damage is reasonably discovered by the property owner. It was further stated in this case that: 'the Plaintiff's loss occurs when the market value of the house is depreciated by reason of the defective foundations and not before'. Lord Lloyd giving judgment recognised that: 'in the common case the occurrence of the loss and the discovery of the loss will coincide', and that the date of the cause of action 'marks the moment when the market value of the building is depreciated and therefore the moment when economic loss occurs'.

Judge Lloyd considered the benefits of the approach of the New Zealand court (over Pirelli) to be as follows:

- it avoids the practical and theoretical difficulties relating to Pirelli;

- it means that a cause of action accrues when all the elements necessary to support the plaintiff's claim are in existence, including the loss or damage to the value of a property necessary to a claim for economic loss in the case of a defect; and

- it means that an undiscoverable crack is irrelevant because it cannot affect the value of the building.

\section{SUMMARY OF WILL GANNON}

The court summarised the position with regard to Murphy as being that the claimant may only sue in tort in respect of a latent defect in the building in the following circumstances:

- for personal injury;

- for damage to property caused by a latent defect in a building; and

- for economic loss where there is a special relationship between the parties.

The court conceded, however, that the decision in Murphy leaves it unclear as to whether this extends to damage to the building itself before the defect is discovered. In addition, the definition of a 'special relationship' is unclear as discussed in Will Gannon. 'It is clear that the duty in such case extends to taking care not to cause economic loss, but 
when does such loss occur in a case such as the present and does the duty not to cause physical damage to property constitute a separate cause of action for limitation purposes?'

The engineer's argument was that:

- the claimant had only suffered economic loss;

- loss occurred when the defectively designed work to the bay window was completed, ie March 1997 (the economic loss had been suffered at this point as the claimant's building was defective at this point); and

- the cause of action for negligent design accrued when the economic loss was first suffered.

The court decided, however, that it was bound by the decisions in Pirelli and Ketteman to uphold the first instance decision of the District Judge, namely that the cause of action accrued when physical damage to the building first occurred. The reasoning behind this seems to have been as follows:

\section{Summary}

- the facts in Pirelli are indistinguishable from the facts in Will Gannon;

- Pirelli was approved in Ketteman;

- Pirelli was cited without disapproval in Murphy (and two members, ie Lords Bridge and Brandon, were party to the decisions in both Pirelli and Murphy);

- Pirelli had not been expressly overruled, and the court considered that Pirelli had not been impliedly overruled. In particular, reference was made to the comments made in Invercargill that, while Pirelli was not good law in New Zealand, it was not for the New Zealand court to say whether or not it was good law in England; and

- only the House of Lords can decide whether Pirelli has been overruled.

The court went on to deal with the position in the event that it was not bound by Pirelli and the claimant's cause of action accrued at the time when economic loss was suffered. The court decided that the cause of action accrued in 1999 and the claim was not therefore time barred. The basis of this decision was as follows:

- that the economic loss did not occur in March 1997 (as argued by the defendant's engineers) because the defective design had not caused any loss at that time;

- the loss would occur with the cost of repairs or depreciation in the market value; and

- the court accepted the analysis in Invercargill which avoids practical and theoretical difficulties with the timing of the loss and discovery of the defects coinciding.

\section{CONCLUSION}

This is an important case, particularly for construction professionals. It is noteworthy that the Court of Appeal's view was that the House of Lords was the appropriate court (if necessary) to overrule Pirelli. It is significant 
to note that a claim for $£ 20,000$ got as far as the Court of Appeal and it is highly unlikely that it will proceed further in costly appeals. It will be interesting to see if the House of Lords does take the opportunity, in the near future, to clarify the position, which can only help claimants and professionals alike.

The judge in Will Gannon stated: 'So what is the present state of the law of England? With three House of Lords' cases to guide us it ought to be possible to give a clear answer to this question, but I regret that I feel unable to do so with any confidence.' Unfortunately, this not only shows how the law can change but also that it is definitely not an exact science. The effect of Will Gannon is obviously reduced where a contract is executed under deed (as this increases the time in which a claimant may bring proceedings under contract from six to 12 years). But professionals rarely enter into contracts under deed. It now seems that 'discoverability' is the key concept and the court is moving nearer to the New Zealand concept where the loss and discovery of defects usually will need to coincide before time starts to run.

\section{APPENDIX: EXTRACTS FROM THE LIMITATION ACT 1980}

\section{Time limit for actions founded on tort}

An action founded on tort shall not be brought after the expiration of six years from the date on which the cause of action accrued.

\section{Time limit for actions founded on simple contract}

An action founded on simple contract shall not be brought after the expiration of six years from the date on which the cause of action accrued.

\section{Time limit for actions on a specialty}

(1) An action upon a specialty shall not be brought after the expiration of twelve years from the date on which the cause of action accrued.

(2) Subsection (1) above shall not affect any action for which a shorter period of limitation is prescribed by any other provision of this Act.

\section{A. Special time limit for negligence actions where facts relevant to cause of action are not known at date of accrual}

(1) This section applies to any action for damages for negligence, other than one to which Section 11 of this Act applies, where the starting date for reckoning the period of limitation under subsection (4)(b) below falls after the date on which the cause of action accrued.

(2) Section 2 of this Act shall not apply to an action to which this section applies.

(3) An action to which this section applies shall not be brought after the expiration of the period applicable in accordance with subsection (4) below.

(4) That period is either:

(a) six years from the date on which the cause of action accrued; or

(b) three years from the starting date as defined by subsection (5) below, if that period expires later than the period mentioned in paragraph (a) above. 
(5) For the purposes of this section, the starting date for reckoning the period of limitation under subsection (4)(b) above is the earliest date on which the plaintiff or any person in whom the cause of action was vested before him first had both the knowledge required for bringing an action for damages in respect of the relevant damage and a right to bring such an action.

(6) In subsection (5) above 'the knowledge required for bringing an action for damages in respect of the relevant damage' means knowledge both:

(a) of the material facts about the damage in respect of which damages are claimed; and

(b) of the other facts relevant to the current action mentioned in subsection (8) below.

(7) For the purposes of subsection (6)(a) above, the material facts about the damage are such facts about the damage as would lead a reasonable person who had suffered such damage to consider it sufficiently serious to justify his instituting proceedings for damages against a defendant who did not dispute liability and was able to satisfy a judgment.

(8) The other facts referred to in subsection (6)(b) above are:

(a) that the damage was attributable in whole or in part to the act or omission which is alleged to constitute negligence; and

(b) the identity of the defendant; and

(c) if it is alleged that the act or omission was that of a person other than the defendant, the identity of that person and the additional facts supporting the bringing of an action against the defendant.

(9) Knowledge that any acts or omissions did or did not, as a matter of law, involve negligence is irrelevant for the purposes of subsection (5) above.

(10) For the purposes of this section a person's knowledge includes knowledge which he might reasonably have been expected to acquire:

(a) from facts observable or ascertainable by him; or

(b) from facts ascertainable by him with the help of appropriate expert advice which it is reasonable for him to seek;

but a person shall not be taken by virtue of this subsection to have knowledge of a fact ascertainable only with the help of expert advice so long as he has taken all reasonable steps to obtain (and, where appropriate, to act on) that advice. 